\title{
The effects of branch-chain amino acids on fatigue in the athletes
}

\author{
IMANIPOUR VAHID $^{1, *}$, BANAIIFAR ABDOLALI $^{2}$, MAHDI FATEMEH $^{1}$, NADERI ALIREZA $^{1}$, \\ SADEGHI MEHDI ${ }^{3}$
}

\author{
${ }^{1}$ Department of Physical Education and Sport Sciences, Parand Branch, Islamic Azad University, Tehran, Iran \\ ${ }^{2}$ Faculty of Physical Education and Sport Sciences, South Tehran Branch, Islamic Azad University, Tehran, Iran \\ ${ }^{3}$ Shiraz Branch, Islamic Azad University, Shiraz, Iran \\ *Corresponding author: Imanipour Vahid; Department of Physical Education and Sport Sciences, Parand Branch, Islamic Azad University, \\ New City of Parand, Tehran 3761396361, Iran; Phone: +98 9368363655; Fax: +98 2156733081; E-mail: vhim918@gmail.com
}

(Received: January 14, 2018; Revised manuscript received: January 18, 2018; Accepted: January 23, 2018)

\begin{abstract}
Research has shown that injection of a mixture of amino acids into humans led to stimulation of protein synthesis about 30 min after injection, and the synthesis rate remained at a high level for up to $90 \mathrm{~min}$. Various theories have been proposed to justify this effect, such as increasing the availability of amino acids in the body to increase their transmission to muscle, and this increase in transmission can stimulate the synthesis of protein in muscle cells. A total of 30 volunteers with a history of 2-3 years in the field of Athletics were participated in this study. The experimental group (15 subjects) used BCAAs supplement during 6-week athletics training. Control group (15 subjects) participated in athletics training for 6 weeks without any supplementation. Blood was taken before and after 6 weeks supplementary. The findings of the $t$-test showed that basal levels of lactate and ammonium had not changed significantly after 42 days of supplementation. The results of this study showed that BCAAs supplementation has no effect on the reduction of lactate and ammonium indices as indicators of fatigue.
\end{abstract}

Keywords: BCAAs, lactate, ammonium, exercise training, athletics

\section{Introduction}

Branch-chain amino acids (BCAAs) containing leucine, isoleucine, and valine are essential amino acids for humans, and among athletes, many people use high amounts of these amino acids.

Research on human muscle shows that BCAAs have anabolic effects on protein metabolism by increasing the rate of protein synthesis or decreasing its decomposition rate, or both $[1,2]$.

The research has shown that injection of a mixture of amino acids into humans led to stimulation of protein synthesis about $30 \mathrm{~min}$ after injection, and the synthesis rate remained at a high level for up to $90 \mathrm{~min}$ [3]. Various theories have been proposed to justify this effect, such as increasing the availability of amino acids in the body to increase their transmission to muscle, and this increase in transmission can stimulate the synthesis of protein in muscle cells [4].
Today, it is known that leucine stimulates the release of insulin from the pancreas and generally applied the effect of leucine in this way [5]. Although little information is still available on the activity of signals on protein synthesis, this makes it difficult to accurately determine the mechanism of BCAAs' effect on protein synthesis [6]. Therefore, the reasons for the effect of BCAAs on increased muscle protein synthesis and, ultimately, increased muscle mass, which lead to decreased fatigue in exercise, are still uncertain [7].

\section{Materials and Methods}

Thirty track and field athlete volunteers with a history of 2-3 years in the field of Athletics participated in this study. The experimental group ( 15 subjects) used BCAAs supplement during 6 weeks training. Control group (15 subjects) participated in training program for 6 weeks

This is an open-access article distributed under the terms of the Creative Commons Attribution-NonCommercial 4.0 International License, which permits unrestricted use, distribution, and reproduction in any medium for non-commercial purposes, provided the original author and source are credited, a link to the CC License is provided, and changes - if any - are indicated. 


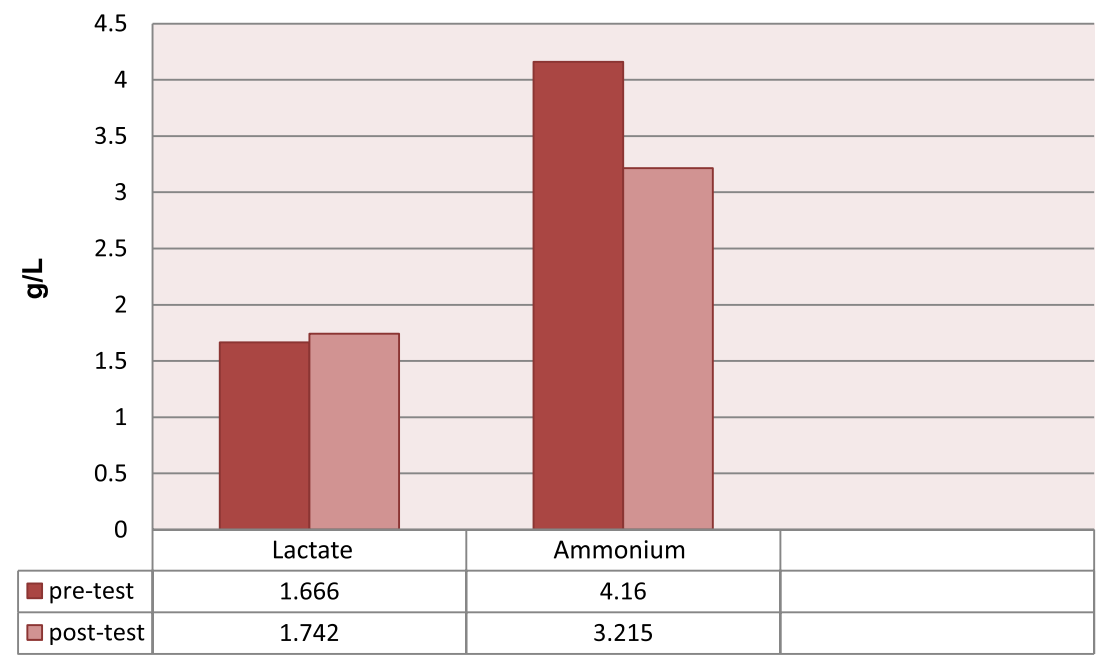

Fig. 1. Lactate and ammonium concentration in BCAAs group

without any supplementation. The blood sampling took before and after 6 weeks of training and immediately after participating in the Astrand test on an ergometer. All samples were obtained to determine the concentration of lactate and ammonium. The data were analyzed by $t$-test (SPSS 16).

\section{Results}

The findings of the $t$-test showed that although basal levels of lactate in this group increased slightly after 42 days of supplementation, this difference was not statistically significant.

In addition, although the base levels of ammonium index in this group decreased slightly after 42 days of supplementation, this difference was not statistically significant (Fig. 1).

\section{Discussion}

Central fatigue theory was introduced in 1987 as an important mechanism of communication with increasing fatigue during long training in sports science societies [8].

Therefore, research on the impact of supplements containing amino acids, including BCAAs, in this area has began and continued ever. Spodaryk et al. [9] first investigated the impact of BCAAs on physical functionings on 193 marathon athletes in Sweden and received significant reductions in marathon time in the BCAAs consumer group. Another study reported that the effect of this amino acid on athletes during exercise in hot weather increased by $14 \%$ in the intensity of exercising with low intensity (40\% maximal oxygen consumption) [10].
On the other hand, two other studies that did not consider BCAAs effects on cyclists had any significant effect on performance capacity $[11,12]$. In another study, two different BCAAs doses were observed in cyclists and no significant change was observed in performance capacity [13]. However, in another study, $40 \mathrm{~kg}$ of cyclists and $12 \%$ of BCAA per day for 2 weeks reported a decrease in fatigue [14].

Colombani et al. [15] examined the effect of BCAAs using in athletes, although they did not see a significant effect on their athletic performance, but a significant change was observed in recovery and immune system. Also, McConell et al. [16] measured the effect of BCAAs on Rhymes' immune responses and reported that BCAAs' use led to an increase in interleukin 2 (IL-2) and interferon production after exercise, and IL-4 decreased. Also, Shimomura et al. [17] examined the effect of this amino acid on Scott's motion in non-athletes and reported lesser bruising in the BCAA consumer group than in the control group.

\section{Conclusions}

The results of this study showed that BCAAs supplementation has no effect on the reduction of lactate and ammonium indices as indicators of fatigue. Although some studies have reported significant changes in this regard, these differences may occur for the following reasons:

- The difference in the community of participant in the studies mentioned in this research.

- Differences in BCAAs supplement alone or in combination with other supplements.

- Differences in the type of exercise practice. 


\section{References}

1. Alvestrand A, Hagenfeldt L, Merli K, Oureshi A, Eriksson LS: Influence of leucine infusion on intracellular amino acids in humans. Eur J Clin Invest 20, 293-298 (1990)

2. Nair KS, Schwartz RG, Welle S: Leucine as a regulator of whole body and skeletal muscle protein metabolism in humans. Am J Physiol 263, E928-E934 (1992)

3. Bohé J, Low JFA, Wolfe RR, Rennie MJ: Latency and duration of stimulation of human muscle protein synthesis during continuous infusion of amino acids. J Physiol 532, 575-579 (2001)

4. Wolfe RR: Effects of amino acid intake on anabolic processes. Can J Appl Physiol 26, S220-S227 (2001)

5. Anthony JC, Anthony TG, Layman DK: Leucine supplementation enhances skeletal muscle recovery in rats following exercise. J Nutr 129, 1102-1106 (1999)

6. Levenhagen DK, Gresham JD, Carlson MG, Maron DJ, Borel MJ, Flakoll PJ: Postexercise nutrient intake timing in humans is critical to recovery of leg glucose and protein homeostasis. Am J Physiol Endocrinol Metab 280, E982-E993 (2001)

7. Anthony JC, Yoshizawa F, Anthony TG, Vary TC, Jefferson LS, Kimball SR: Leucine stimulates translation initiation in skeletal muscle of postabsorptive rats via a rapamycin-sensitive pathway. J Nutr 130, 2413-2419 (2000)

8. Liua TH, Wub CL, Chiangc CW, Lod YW, Tsenge HF, Changc CK: No effect of short-term arginine supplementation on nitric oxide production, metabolism and performance in intermittent exercise in athletes. J Nutr Biochem 20, 462-464 (2009)

9. Spodaryk K, Szmatlan U, Berger L: The relationship of plasma ammonia and lactate concentrations to perceived exertion in trained and untrained women. Eur J Appl Physiol Occup Physiol 61, 309$312(1990)$

10. Mutch BJ, Banister EW: Ammonia metabolism in exercise and fatigue: A review. Med Sci Sports Exerc 15, 41-50 (1983)

11. Denis C, Dormois D, Linossier MT, Eychenne JL, Hauseux P, Lacour JR: Effect of arginine aspartate on the exercise-induced hyperammoniemia in humans: A two periods cross-over trial. Arch Int Physiol Biochim Biophys 99, 123-127 (1991)

12. Siconolfi SF, Cullinane EM, Carleton RA, Thompson PD: Assessing VO2max in epidemiological studies: Modification of the AstrandRhyming test. Med Sci Sports Exerc 14, 335-338 (1982)

13. Oyono-Enguelle S, Freund H, Ott C, Gartner M, Heitz A, Marbach J, Maccari F, Frey A, Bigot H, Bach AC: Prolonged submaximal exercise and L-carnitine in human. Eur J Appl Physiol Occup Physiol 58, 53-61 (1988)

14. Wideman L, Weltan JY, Patrie JT, Bowers CY, Shah N, Story S, Veldhuis JD, Weltman A: Synergy of L-arginine and GHRP-2 stimulation of growth hormone in men. Am J Physiol 279, Rl467-R1477 (2000)

15. Colombani PC, Bitzi R, Frey-Rindova P, Frey W, Arnold M, Langhans W, Wenk C: Chronic arginine aspartate supplementation in runners reduces total plasma amino acid level at rest and during a marathon. Eur J Nutr 38, 263-270 (1999)

16. McConell GK, Huynh NN, Lee-Young RS, Canny BJ, Wadley GD: $\mathrm{L}$-Arginine infusion increases glucose clearance during prolonged exercise in humans. Am J Physiol 290, E60-E66 (2006)

17. Shimomura $\mathrm{Y}$, Inguma A, Watanabe S, Yamamoto Y, Bajotto G: Branched-chain amino acid supplementation before squat exercise and delayed-onset muscle soreness. Int J Sport Nutr Exerc Metab 20, 236-244 (2010) 